\title{
Patterns of Water and Heat Flux Across a Biome Gradient From Tropical Forest to Savanna in Brazil
}

\section{Citation}

da Rocha, Humberto R., Antonio O. Manzi, Osvaldo M. Cabral, Scott D. Miller, Michael L. Goulden, Scott R. Saleska, Natalia R. Coupe, et al. 2009. Patterns of water and heat flux across a biome gradient from tropical forest to savanna in Brazil. Journal of Geophysical Research 114(G00B12): $1-8$

\section{Published Version}

http://dx.doi.org/10.1029/2007JG000640

\section{Permanent link}

http://nrs.harvard.edu/urn-3:HUL.InstRepos:3138565

\section{Terms of Use}

This article was downloaded from Harvard University's DASH repository, and is made available under the terms and conditions applicable to Other Posted Material, as set forth at http:// nrs.harvard.edu/urn-3:HUL.InstRepos:dash.current.terms-of-use\#LAA

\section{Share Your Story}

The Harvard community has made this article openly available.

Please share how this access benefits you. Submit a story.

\section{Accessibility}




\title{
Patterns of water and heat flux across a biome gradient from tropical forest to savanna in Brazil
}

\author{
Humberto R. da Rocha, ${ }^{1}$ Antonio O. Manzi, ${ }^{2}$ Osvaldo M. Cabral, ${ }^{3}$ Scott D. Miller, ${ }^{4}$ \\ Michael L. Goulden, ${ }^{5}$ Scott R. Saleska, ${ }^{6}$ Natalia R.-Coupe, ${ }^{6}$ Steven C. Wofsy, ${ }^{7}$ \\ Laura S. Borma, ${ }^{1}$ P. Artaxo, ${ }^{1}$ George Vourlitis, ${ }^{8}$ José S. Nogueira, ${ }^{9}$ Fernando L. Cardoso, ${ }^{10}$ \\ Antonio D. Nobre, ${ }^{2}$ Bart Kruijt, ${ }^{11}$ Helber C. Freitas, ${ }^{1}$ Celso von Randow, ${ }^{2}$ \\ Renata G. Aguiar, ${ }^{10}$ and Jair F. Maia ${ }^{2}$
}

Received 30 October 2007; revised 29 September 2008; accepted 11 November 2008; published 17 January 2009.

[1] We investigated the seasonal patterns of water vapor and sensible heat flux along a tropical biome gradient from forest to savanna. We analyzed data from a network of flux towers in Brazil that were operated within the Large-Scale Biosphere-Atmosphere Experiment in Amazonia (LBA). These tower sites included tropical humid and semideciduous forest, transitional forest, floodplain (with physiognomies of cerrado), and cerrado sensu stricto. The mean annual sensible heat flux at all sites ranged from 20 to $38 \mathrm{Wm}^{-2}$, and was generally reduced in the wet season and increased in the late dry season, coincident with seasonal variations of net radiation and soil moisture. The sites were easily divisible into two functional groups based on the seasonality of evaporation: tropical forest and savanna. At sites with an annual precipitation above $1900 \mathrm{~mm}$ and a dry season length less than 4 months (Manaus, Santarem and Rondonia), evaporation rates increased in the dry season, coincident with increased radiation. Evaporation rates were as high as $4.0 \mathrm{~mm} \mathrm{~d}^{-1}$ in these evergreen or semidecidous forests. In contrast, ecosystems with precipitation less than $1700 \mathrm{~mm}$ and a longer dry season (Mato Grosso, Tocantins and São Paulo) showed clear evidence of reduced evaporation in the dry season.

Evaporation rates were as low as $2.5 \mathrm{~mm} \mathrm{~d}^{-1}$ in the transitional forests and $1 \mathrm{~mm} \mathrm{~d}^{-1}$ in the cerrado. The controls on evapotranspiration seasonality changed along the biome gradient, with evaporative demand (especially net radiation) playing a more important role in the wetter forests, and soil moisture playing a more important role in the drier savannah sites.

Citation: da Rocha, H. R., et al. (2009), Patterns of water and heat flux across a biome gradient from tropical forest to savanna in Brazil, J. Geophys. Res., 114, G00B12, doi:10.1029/2007JG000640.

\section{Introduction}

[2] The partitioning of surface energy between evapotranspiration and sensible heat flux in the tropics is important for both the functioning of natural ecosystems and the development of regional climatic patterns. The combination of sensible and latent heat flux controls humidity and thermal stability of the planetary boundary layer, triggers convective rainfall, and ultimately helps to control regional precipitation, soil moisture and climate. Terrestrial ecosys-

\footnotetext{
${ }^{1}$ Departamento de Ciências Atmosféricas, IAG, Universidade de São Paulo, Sao Paulo, Brazil.

${ }^{2}$ Instituto Nacional de Pesquisas da Amazônia, Manaus, Brazil.

${ }^{3}$ Embrapa Meio Ambiente, Jaguariuna, Brazil.

${ }^{4}$ Atmospheric Sciences Research Center, State University of New York at Albany, Albany, New York, USA.

${ }^{5}$ Department of Earth System Science, University of California, Irvine, California, USA.

Copyright 2009 by the American Geophysical Union. 0148-0227/09/2007JG000640\$09.00
}

tems provide ecosystem services, such as catchment discharge, that are a function of evapotranspiration and that can be altered by land use or climate change. Approximately half of the precipitation falling in Amazonia evaporates, of which less than half is recycled as precipitation in the basin [Dirmeyer and Brubaker, 2007; Costa and Foley, 1999]. Previous estimates of the mean annual evapotranspiration in Amazonia based on model simulations range from 2.7 to $5.2 \mathrm{~mm} \mathrm{~d}^{-1}$, with an average of

\footnotetext{
${ }^{6}$ Department of Ecology and Evolutionary Biology, University of Arizona, Tucson, Arizona, USA.

${ }^{7}$ Department of Earth and Planetary Sciences, Harvard University, Cambridge, Massachusetts, USA.

${ }^{8}$ Biological Sciences Department, California State University, San Marcos, California, USA. Brazil.

${ }^{9}$ Department of Physics, Universidade Federal de Mato Grosso, Cuiabá,

${ }^{10}$ Universidade Federal de Rondonia, Porto Velho, Brazil.

${ }^{11}$ Wageningen University and Research, Wageningen, Netherlands.
} 


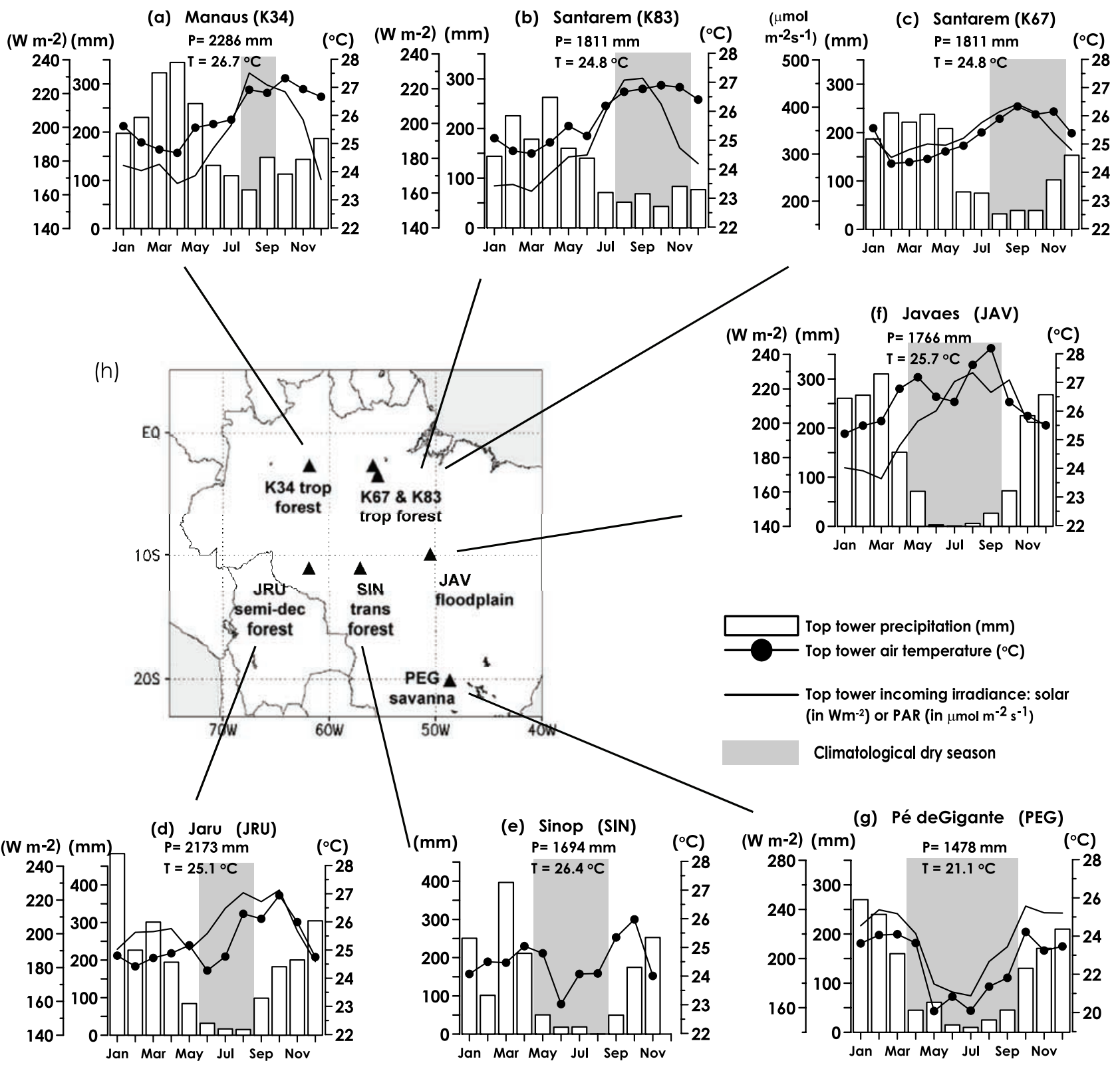

Figure 1. Measured above-canopy mean monthly precipitation (white bar, in mm), air temperature (heavy line with filled circles, in ${ }^{\circ} \mathrm{C}$ ) and incoming irradiance (heavy line) (solar, in $\mathrm{Wm}^{-2}$, or PPFD, in $\mu \mathrm{mol}^{-2} \mathrm{~s}^{-1}$ ) at the flux tower sites displayed in (h) map, namely: (a) K34, (b) K83, (c) K67, (d) JRU, (e) SIN, (f) JAV and (g) PEG (see code ID in Table 1). The climatological dry season is shaded, climatological mean annual precipitaiton (in $\mathrm{mm}$ ) and surface air temperature (in ${ }^{\circ} \mathrm{C}$ ) are displayed at each top panel.

$3.9 \mathrm{~mm} \mathrm{~d}^{-1}$, while estimates based on field observations include $3.5 \mathrm{~mm} \mathrm{~d}^{-1}$ [Shuttleworth, 1988; da Rocha et al., 2004], $3.7 \mathrm{~mm} \mathrm{~d}^{-1}$ [von Randow et al., 2004] and $3.1 \mathrm{mmd}^{-1}$ [Hutyra et al., 2007]. The potential impact of forest to pasture conversion on temperature and precipitation patterns in Amazonia as a result of changes in the surface energy budget [Gash et al., 1996], as well as the potential for forest collapse due to global warming-induced drought [Betts et al., 2004; Friedlingstein et al., 2006], remain very poorly understood.
[3] The Large-Scale Biosphere-Atmosphere Experiment in Amazonia (LBA) was motivated in part by the need for improved observations of evapotranspiration and sensible heat flux in the tropics. Scientists within LBA operated eddy covariance towers at several sites, including ones in tropical humid and semideciduous forest, transitional forest, floodplain, and cerrado sensu stricto. We analyzed data from these towers to better understand the seasonal patterns of water vapor and sensible heat flux across Amazonia. We organized our analysis along a large-scale biome and water 
Table 1. Overview of Brazilian Flux Tower Sites Included in the Analysis ${ }^{\mathrm{a}}$

\begin{tabular}{|c|c|c|c|c|c|c|c|c|c|c|c|}
\hline \multirow[b]{2}{*}{$\begin{array}{l}\text { Code } \\
\text { ID }\end{array}$} & \multirow[b]{2}{*}{ References $^{\mathrm{b}}$} & \multirow{2}{*}{$\begin{array}{c}\text { Locality } \\
\text { (Latitude }{ }^{\circ} \mathrm{S}, \\
\text { Longitude }{ }^{\circ} \mathrm{W} \text { ) }\end{array}$} & \multirow[b]{2}{*}{ Ecosystem Type } & \multicolumn{8}{|c|}{ Period of Measurements } \\
\hline & & & & 1999 & 2000 & 2001 & 2002 & 2003 & 2004 & 2005 & 2006 \\
\hline K34 & 1 & Manaus $(02.60,60.20)$ & Tropical humid forest & $\mathrm{X}$ & $\mathrm{X}$ & $\mathrm{X}$ & $\mathrm{X}$ & $\mathrm{X}$ & $\mathrm{X}$ & $\mathrm{X}$ & $\mathrm{X}$ \\
\hline K67 & 2 & Santarem $(02.85,54.95)$ & Tropical humid forest & & & & & $\mathrm{X}$ & $\mathrm{X}$ & $\mathrm{X}$ & \\
\hline K83 & 3 & Santarem $(03.01,54.97)$ & Tropical humid forest & & $\mathrm{X}$ & $\mathrm{X}$ & $\mathrm{X}$ & $\mathrm{X}$ & & & \\
\hline JRU & 4 & JiParana $(10.08,61.93)$ & Tropical semideciduous forest & $\mathrm{X}$ & $\mathrm{X}$ & $\mathrm{X}$ & $\mathrm{X}$ & & & & \\
\hline SIN & 5 & Sinop $(11.24,55.19)$ & Transitional forest (Cerradão) & $\mathrm{X}$ & & $\mathrm{X}$ & & & & & \\
\hline JAV & 6 & Rio Javaés $(09.82,50.15)$ & $\begin{array}{l}\text { Floodplain } \\
\text { (Cerradão-Cerrado-Grassland) }\end{array}$ & & & & & & $X$ & $\mathrm{X}$ & $\mathrm{X}$ \\
\hline PEG & 7 & Pé deGigante $(21.61,47.64)$ & Cerrado sensu stricto & & & $\mathrm{X}$ & $\mathrm{X}$ & $\mathrm{X}$ & & & \\
\hline
\end{tabular}

${ }^{\mathrm{a}}$ The short-code identifier for each site is used in the text.

${ }^{b}$ Detailed descriptions of sites are available in the following references: 1, Araujo et al. [2002]; 2, Saleska et al. [2003]; 3, Goulden et al. [2004] and Miller et al. [2004]; 4, von Randow et al. [2004]; 5, Vourlitis et al. [2002]; 6, Borma et al. [2009]; 7, also, da Rocha et al. [2002].

balance gradient, from comparatively wet sites, which were dominated by evergreen forest, to a dry site, which was dominated by cerrado sensu stricto.

\section{Methods}

[4] We used field measurements collected at seven flux tower sites in Brazil (see map of Figure 1 and site description in Table 1). We refer to these sites by the abbreviations in Table 1. Three of these sites were tropical terra firme humid forests, which were near $3^{\circ} \mathrm{S}$ (Manaus K34, Santarem K83 and Santarem K67). These sites had 30-40 m tall closed canopies of evergreen trees, with occasional palms and lianas. Soils at these sites were yellow clay latosols (Oxisol or Haplic Acrorthox). Three other sites were near $10^{\circ} \mathrm{S}$. The Rondonia (JRU) site was a tropical terra firme humid forest with a $35 \mathrm{~m}$ closed canopy and a sparse palm and liana understory. Soil at JRU was a podsol (Arenosol) with high sand and silt content. The transitional Mato Grosso site (SIN) was a woodland savanna with $28-$ $30 \mathrm{~m}$ tall trees (cerradão) over sandy soil (quartzarenic neosoil). The floodplain site at Tocantins (JAV), about $1 \mathrm{~km}$ east of the Javaes river on the border of Bananal Island, included a mixture of cerradão (tall woodland savanna with $18 \mathrm{~m}$ tall trees and sparse shrubs), cerrado (dense scrub with $5 \mathrm{~m}$ tall trees and grass understory) and campo (natural grassland). The soil at JAV was hydromorphic sandy (Gley humic). Although the JAV site was within a large region classified as ecotone (Brazilian Institute of Geographic Statistics (IBGE)), the landscape at the tower was not strictly ecotonal [Neiff, 2003], and the different ecosystem types contacted each other along well-defined boundaries. The southernmost site (PEG), which was near $20^{\circ} \mathrm{S}$ in São Paulo, consisted of cerrado sensu stricto, a closed scrub with 5-10 m tall trees, a dense herbaceous understory, and deep sandy soil (quartzarenic neosoil).

[5] The data presented include climatological variables and surface heat and water vapor atmospheric fluxes measured above the vegetation canopies. Hourly turbulent energy fluxes were measured using the eddy covariance method, defined as the covariance of vertical wind velocity with temperature for the sensible heat flux $(H)$, or vertical wind velocity with water vapor for the latent flux $(L E)$. The climate data include air temperature, net radiation $(R n)$, soil heat flux $(G)$, incoming solar or PPFD irradiances, and accumulated precipitation. Monthly mean values were calculated for the periods with available data for each site (Table 1). Detailed information on soil and climate, data acquisition, and flux processing methods were reported previously (Araújo et al. [2002] for K34; Saleska et al. [2003] and Hutyra et al. [2007] for K67; Goulden et al. [2004], Miller et al. [2004], and da Rocha et al. [2004] for K83; von Randow et al. [2004] for RJU; Borma et al. [2009] for JAV; da Rocha et al. [2002] for PEG; and Vourlitis et al. [2002] for SIN).

\section{Results and Discussion}

\subsection{Climate}

[6] The annual rainfall decreased, and the length of the dry season increased, from west to east and north to south. The annual precipitation (Figure 1) was greatest at the K34 and JRU sites (above $2100 \mathrm{~mm}$ ), followed by K67 and K83 $(1911 \mathrm{~mm})$, JAV and SIN $(\approx 1700 \mathrm{~mm})$, and PEG $(1478 \mathrm{~mm})$. The southernmost site $(\mathrm{PEG})$, which was dominated by savanna, had the longest dry season, lasting 6 months from April and August (Figure 1). The seasonality of precipitation measured at all of the sites was consistent with the climatology for the region (Figures $1 \mathrm{a}-1 \mathrm{~g}$ ). The JAV site was flooded for 2-5 months each year in the wet season by the Javaesinho river, usually from January and May.

[7] Air temperature (Figure 1) peaked in September and October at all sites except PEG, where the maximum was in February (Figure 1g). The air temperature at the sites near $3^{\circ}$ and $10^{\circ} \mathrm{S}$ was $24^{\circ}$ to $27^{\circ} \mathrm{C}$ year-round. SIN was the coolest of these sites (minimum was $23^{\circ} \mathrm{C}$ ) and JAV the warmest (maximum was $28^{\circ} \mathrm{C}$ ). PEG was the coldest site overall, with mean monthly temperatures from $20^{\circ}$ to $24^{\circ} \mathrm{C}$. The dry season lasted until about November at ManausK34, and until about December at Santarem (K67 and K83). The air temperature at JRU, JAV and SIN showed bimodal variation, with a minimum in June/July around the solstice, and a secondary minimum during December/January, coinciding with the precipitation maximum (Figures 1d-1f). This bimodal pattern is in agreement with the 30-year climatological normals for the region [Inmet, 1994].

[8] The seasonal variation of air temperature was well correlated with incoming solar radiation at all sites (Figure 1). The incoming radiation had two maxima per year near the $3^{\circ} \mathrm{S}$ latitudinal belt (around the September and March 
(Rn, LE, H) (a) Manaus (K34)

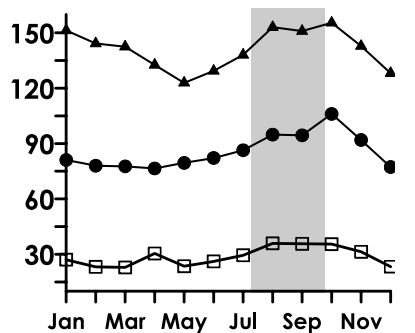

(Rn, LE, H) (b) Santarem (K83)

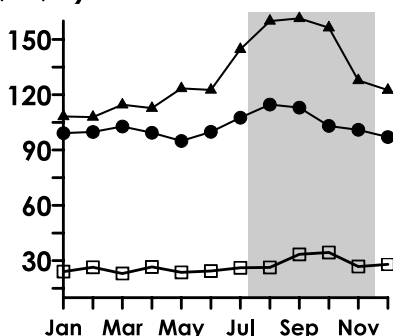

(Rn, LE, H) (c) Santarem (K67)

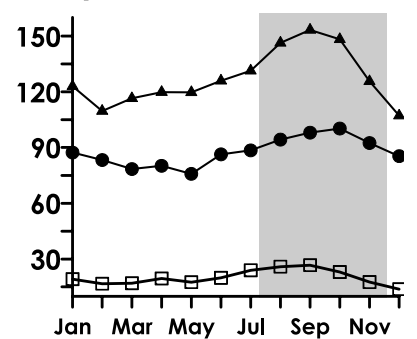

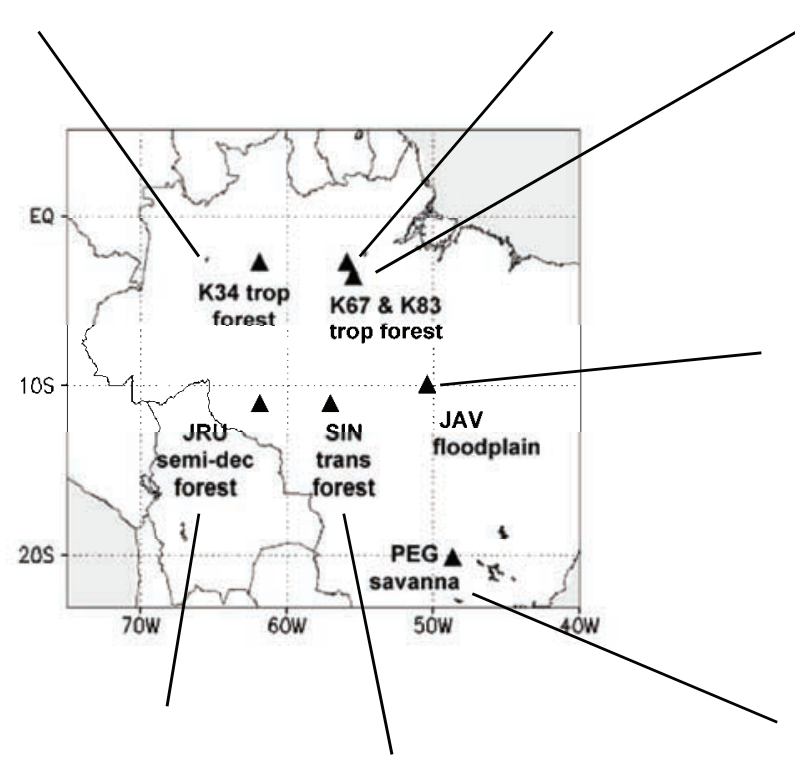

(d) Jaru (JRU)

(Rn, LE, H)

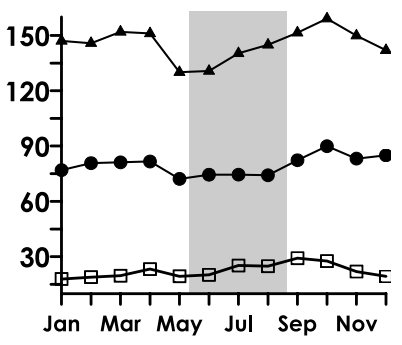

(Rn, LE, H)

(e)

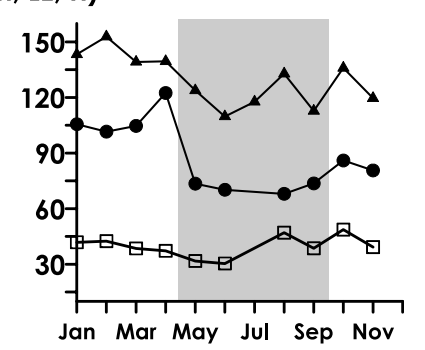

(Rn, LE, H) (f) Javaes (JAV)
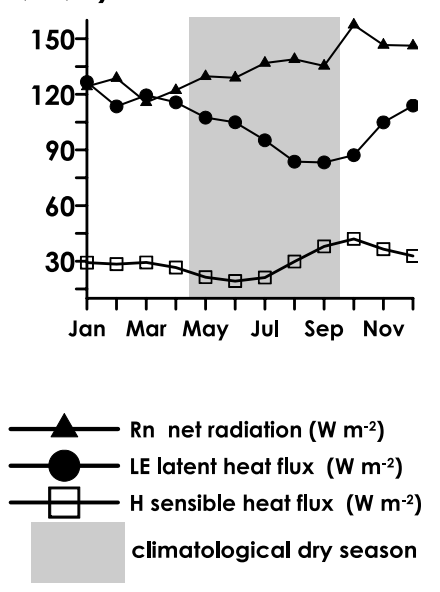

(g) Pe deGigante(PEG)

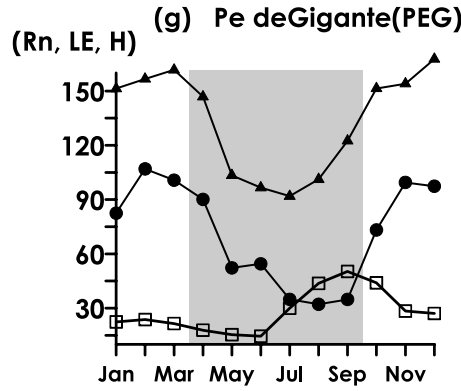

Figure 2. Mean monthly latent heat flux $(L E)$ (line joining filled circles), net radiation $(R)$ (line joining filled triangles) and sensible heat flux $(H)$ (line joining open squares), all in $\mathrm{Wm}^{-2}$, for the sites (a) K34, (b) K83, (c) K67, (d) JRU, (e) SIN, (f) JAV and (g) PEG (see code ID in Table 1). The climatological dry season is shaded.

equinoxes), and a single minimum near the $10^{\circ} \mathrm{S}$ belt (around the June solstice). A decline in temperatures at K34, K67 and K83 during January to May appears to result from increasing cloud cover during the wet season. Increases in temperature at all sites but PEG during the dry season are a result of increasing incoming radiation, reduced cloud cover, and the large scale subsidence. The largest annual amplitude of temperature and incoming solar radiation was observed at $20^{\circ} \mathrm{S}$, and was a result of both more extreme changes in solar elevation angle and the occasional intrusion of strong cold fronts during the winter.

[9] The seasonality of the measured precipitation was consistent with the climatology for the region. A strong drought during 2004/2005 over western and southern Amazonia [Saleska et al., 2007] may have influenced the sites
JRU and SIN. However, the data sets were collected prior to 2003 and therefore were likely not influenced.

\subsection{Seasonal Patterns of Evaporation, Sensible Heat, and Net Radiation}

[10] The seasonal patterns of monthly net radiation, sensible heat flux, and latent heat flux, which we also refer to as evapotranspiration or ET, differed markedly between sites. ET at K34, K67 and K83 was lowest in the wet season, reaching seasonal minima of 80 to $110 \mathrm{Wm}^{-2}$ (Figures $2 \mathrm{a}-2 \mathrm{c}$ ). ET increased in June/July at these sites coinciding with the onset the dry season, before peaking at 110 to $120 \mathrm{Wm}^{-2}$ from August to October. The seasonal patterns in ET at these sites is consistent with a strong control of net radiation on evaporation (Figures 1a-1d). 
Table 2. Average Net Radiation $\left(R_{n}\right)$, Latent Heat Flux $(L E)$, and Sensible Heat Flux $(H)$ in the Dry and Wet Seasons ${ }^{\mathrm{a}}$

\begin{tabular}{|c|c|c|c|c|c|c|c|c|c|}
\hline \multirow[b]{2}{*}{$\underline{\text { Site }}$} & \multicolumn{3}{|c|}{$R_{n}\left(\mathrm{~W} \mathrm{~m}^{-2}\right)$} & \multicolumn{3}{|c|}{$\operatorname{LE}\left(\mathrm{W} \mathrm{m} \mathrm{m}^{-2}\right)$} & \multicolumn{3}{|c|}{$\mathrm{H}\left(\mathrm{W} \mathrm{m} \mathrm{m}^{-2}\right)$} \\
\hline & Dry & Wet & Dry - Wet & Dry & Wet & Dry - Wet & Dry & Wet & Dry - Wet \\
\hline K34 & 153 & 137 & $12 \%$ & 98 & 81 & $21 \%$ & 36 & 26 & $38 \%$ \\
\hline K67 & 143 & 119 & $20 \%$ & 96 & 83 & $16 \%$ & 23 & 18 & $28 \%$ \\
\hline K83 & 146 & 117 & $25 \%$ & 114 & 103 & $11 \%$ & 27 & 24 & $13 \%$ \\
\hline JRU & 142 & 147 & $-3 \%$ & 76 & 81 & $-6 \%$ & 25 & 21 & $19 \%$ \\
\hline SIN & 119 & 138 & $-14 \%$ & 71 & 100 & $-29 \%$ & 37 & 41 & $-10 \%$ \\
\hline JAV & 136 & 135 & $1 \%$ & 94 & 114 & $-17 \%$ & 25 & 32 & $-21 \%$ \\
\hline PEG & 103 & 149 & $-31 \%$ & 39 & 88 & $-56 \%$ & 36 & 25 & $44 \%$ \\
\hline
\end{tabular}

${ }^{\mathrm{a}}$ The dry season averages were calculated during August to October for K34; August to November for K67 and K83; June to September for JRU, SIN and JAV; and May to August for PEG. The wet season average was calculated for the remaining months of the year. The column (dry - wet) is the percent difference between the mean of dry season minus the wet season, relative to the mean wet season. Areas in italic indicate the maximum $R_{n}, L E$ and $H$ between the dry and wet season (at the S.L. $=2 \%$ ).

[11] The ET at JRU peaked early in the wet season (Figure 2d). The low ET at JRU in comparison to the other sites during the early to middle dry season may have resulted from colder temperatures and less net radiation, coinciding with the June solstice (see Figure 1d). However, the ET at JRU did not increase in August coincident with decreased cloud cover and increased radiation, implying that radiation alone doesn't control ET at JRU. A possible explanation is semideciduous species at JRU started to senesce in August, which reduced green leaf area index and transpiration.

[12] In contrast, the ET at SIN, JAV and PEG followed a seasonal pattern that was nearly opposite to that observed at K34, K67 and K83. The mean ET rates at SIN, JAV and PEG decreased progressively with the development of the dry season (Figures $2 \mathrm{e}-2 \mathrm{~g}$ ). Peak monthly ET was between 110 to $120 \mathrm{Wm}^{-2}$ at these sites, and minimal ET was $\approx 70 \mathrm{Wm}^{-2}$ at $\mathrm{SIN}$ and $\mathrm{JAV}$ and $\approx 30 \mathrm{Wm}^{-2}$ at $\mathrm{PEG}$ (Figures $2 \mathrm{e}-2 \mathrm{~g}$ ).

[13] The seasonal patterns of ET at SIN and PEG were positively correlated with net radiation (Figures $2 \mathrm{e}$ and $2 \mathrm{~g}$ ), a pattern that is similar to that observed for the tropical humid forest sites (K34, K67 and K83) and semideciduous forest (JRU) and that illustrates the control that available energy exerts on ET. A contrasting pattern was observed at JAV, where net radiation increased progressively from May through August (the dry season), while ET decreased (Figure 1f). The evaporation from standing water beneath the canopy may have likely dominated the energy exchanges during the wet season at JAV, and must have declined markedly as JAV dried in the dry season [Borma et al., 2009]. The ecosystem at this point functioned similar to a savanna, resulting in a large decrease in ET from May to September, despite increasing radiation.

[14] Net radiation, ET and sensible heat flux for the dry and wet seasons are summarized in Table 2. All three of these energy fluxes increased during the dry season at the evergreen forest sites (K34, K67 and K83). Net radiation at these sites was $143-153 \mathrm{Wm}^{-2}$ in the dry season and $117-$ $137 \mathrm{Wm}^{-2}$ in the wet season. ET was $96-114 \mathrm{Wm}^{-2}$ in the dry season (equivalent to $3.3-3.9 \mathrm{~mm} \mathrm{~d}^{-1}$ ) and $81-$ $103 \mathrm{Wm}^{-2}$ (equivalent to $2.8-3.6 \mathrm{~mm} \mathrm{~d}^{-1}$ ) in the wet season. In contrast, ET was lower in the dry season at SIN, JAV and PEG (39-94 $\mathrm{Wm}^{-2}$; i.e., $1.3-3.3 \mathrm{~mm} \mathrm{~d}^{-1}$ ) than in the wet season $\left(88-111 \mathrm{Wm}^{-2}\right.$; i.e., $\left.2.8-3.8 \mathrm{~mm} \mathrm{~d}^{-1}\right)$ (Table 2). Likewise, net radiation was generally lower in the dry season at these sites (except for JAV, which showed a very modest increase), as was sensible heat flux (except for PEG). The highest seasonal change of ET was observed at PEG, which increased from $39 \mathrm{Wm}^{-2}$ in the dry season $\left(1.3 \mathrm{~mm} \mathrm{~d}^{-1}\right)$ to $88 \mathrm{Wm}^{-2}$ in the wet season $\left(3.0 \mathrm{~mm} \mathrm{~d}^{-1}\right)$.

[15] The sensible heat flux at all sites was reduced during the wet season, with a gradual increase during the dry season, and a maximum during the mid to late dry season (Figure 2). This pattern is consistent with the temporal variation of net radiation, and the plentiful soil moisture in the wet season and moisture deficit in the dry season. Soil moisture decreases substantially during the dry season in savanna [Oliveira et al., 2005], at the floodplain site [Borma et al., 2009], and in tropical humid forest [Bruno et al., 2006], although the decrease does not appear to limit transpiration at forest sites. The seasonal differences of sensible heat fluxes were mostly positive, varying from 19 to $44 \%$, or $20-38 \mathrm{Wm}^{-2}$, for all sites except SIN and JAV (Table 2). SIN and JAV showed negative differences, partly because the sensible heat flux remained high even in the early wet season (Figures $2 \mathrm{f}$ and 2e). Moreover, at JAV the heat flux was low during early to middle dry season, consistent with the relatively wet soil after the flooding.

[16] At all sites, the mean monthly sensible heat flux was lower than the latent heat fluxes (i.e., the Bowen ratio was $<$ 1), except for the PEG site during the middle to late dry season, when it was $>1$.

\subsection{Normalized Surface Fluxes}

[17] The mean net radiation varied considerably between sites during the wet season (from about January through May, $110-150 \mathrm{Wm}^{-2}$, Figure 3a). At all sites except PEG, the mean monthly net radiation increased from $\approx 120$ in May to $150 \mathrm{Wm}^{-2}$ in October, coinciding with the dry season. The similarity in the temporal evolution of net radiation among sites as the dry season progressed was remarkable, considering the variation of incoming solar radiation with latitude, and the potential importance of other factors, such as cloudiness, smoke, surface albedo, and long-wave energy exchange. The annual amplitude of incoming solar radiation was much more pronounced at PEG, with a substantial decrease in net radiation during the southern hemisphere winter.

[18] The absolute values of latent and sensible heat fluxes must be interpreted with caution, as the estimates of turbulent fluxes have potential site-specific uncertainties related to energy balance closure. We calculated the ratio $(H+L E) /\left(R_{n}-G\right)$, to investigate the energy closure at each site, using monthly averages for all sites, excluding $G$ at the K67 site (Table 2). We disregarded energy stored in biomass and canopy air below the measurement height, the chemical energy associated with net $\mathrm{CO}_{2}$ exchange, and energy advected horizontally, which are arguably small when averaged over $24 \mathrm{~h}$ (for example, the energy stored in tropical forest biomass varied between 0 and $2 \mathrm{Wm}^{-2}[\mathrm{da}$ Rocha et al., 2004]). The energy balance closure was lowest $(0.70)$ at PEG and JRU, and higher $(0.85-1.05)$ at the remaining sites. The energy balance closure was consistent 
(a)
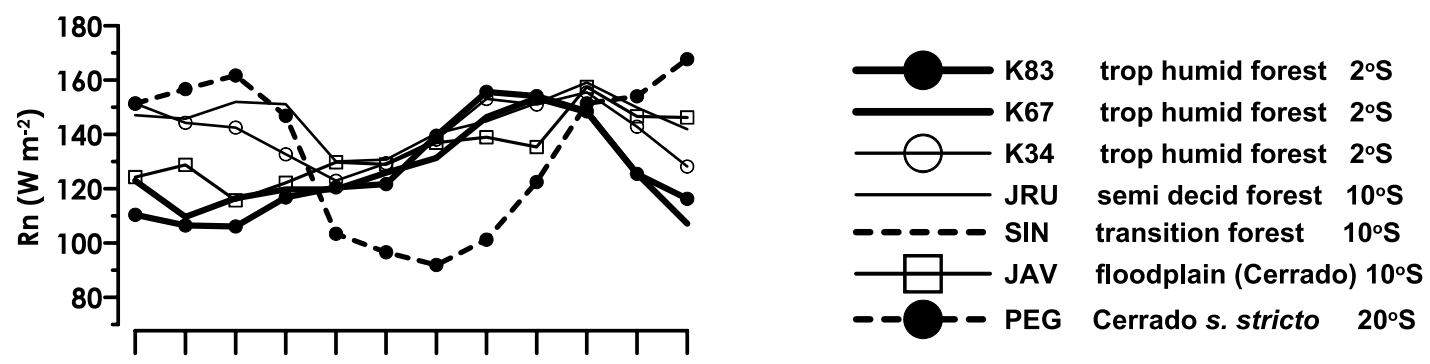

Jan Feb Mar Apr May Jun Jul Aug Sep Oct Nov Dec

(b)

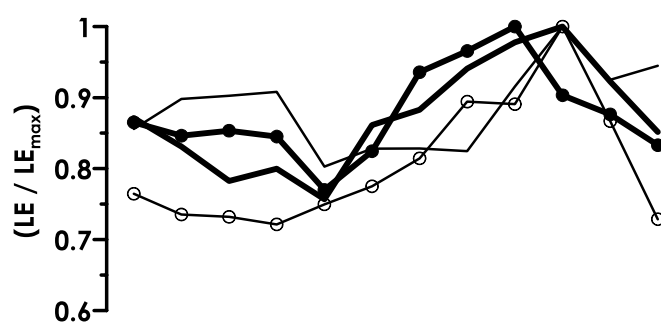

(c)
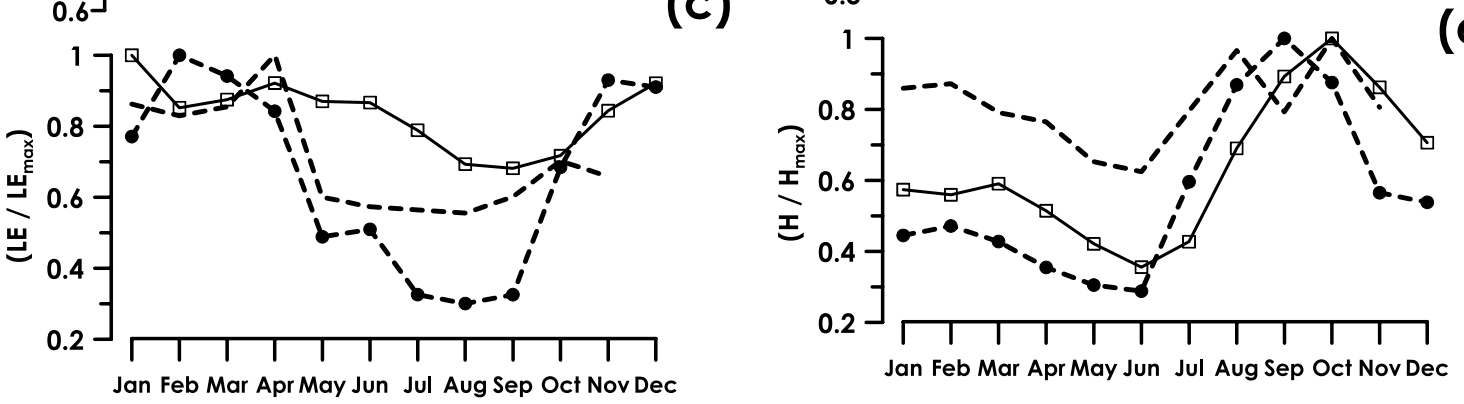

(d)

Figure 3. Mean monthly (a) net radiation $\left(R_{n}\right.$, in $\left.\mathrm{Wm}^{-2}\right)$; (b, c) ratio of monthly mean sensible heat flux to the maximum monthly mean sensible energy flux, $\left(\mathrm{H} / \mathrm{H}_{\max }\right) ;(\mathrm{d}, \mathrm{e})$ ratio of monthly mean latent heat flux to the maximum monthly mean latent energy flux, $\left(\mathrm{LE} / \mathrm{LE} \mathrm{max}_{\text {max }}\right.$; for the following sites: $\mathrm{K} 83$ (heavy line with filled circle), K67 (heavy line), K34 (thin line with open circle), JRU (thin line), SIN (dashed line), JAV (thin line with open square), and PEG (dashed line with filled circle) (see code ID in Table 1).

with the range reported for a range of sites worldwide [Wilson et al., 2002], though they examined half-hourly data, which may lead to lower energy closure when compared to the daily averaged data.

[19] We normalized the energy fluxes by the maximum annual monthly flux $\left(L E_{\max }\right.$ or $\left.H_{\max }\right)$ to facilitate comparison between sites. The seasonal patterns of $L E / L E_{\max }$ were similar at K34, K67, K83 and JRU (Figure 3b). The seasonal patterns of $L E / L E_{\max }$ at these sites were also similar to the seasonal patterns of net radiation, especially in the dry season. The $L E / L E_{\max }$ ratio increased at the end of the wet season and beginning of the dry season (roughly in May), and peaked between September and October. $L E / L E_{\max }$ varied considerably between sites during the wet season (between 0.75 and 0.9 ). The seasonal patterns of $H / H_{\max }$ (Figure $3 \mathrm{~d}$ ) were similar to $L E / L E_{\max }$, with a maximum around September. $H / H_{\max }$ was minimum during the wet season, with a range of $0.6-0.75$. The decline of $H / H_{\max }$ after September was more abrupt than the increase during the dry season, and also more abrupt than the decline of $L E$ / $L E_{\text {max }}$ during the same period. We suspect that soil moisture played a strong role in controlling these variations. Soil moisture depletion progresses smoothly in long dry spells, which would be expected to reduce soil evaporation. On the other hand, early in the wet season there is readily available soil moisture in shallow layers [Bruno et al., 2006] that, together with the flush of green leaves [Goulden et al., 2004] can increase canopy conductance and change the balance between $L E$ and $H$ in such a way that there is a more rapid decrease in sensible heat flux.

[20] The sites JAV, SIN and PEG were characterized by longer and more intense dry seasons than were the other sites. The seasonal patterns of $H / H_{\max }$ were broadly similar to that at the wetter sites (Figure $3 \mathrm{e}$ ). In contrast, $L E / L E_{\max }$ at JAV, SIN and PEG decreased during the dry season (Figure 3c), and was quite different from that at the wetter 
sites. The maximum $L E / L E_{\max }$ at JAV, SIN, and PEG occurred during the middle or late wet season (December to March), and the minimum $L E / L_{\max }$ occurred around September, which is at the end of the dry season. The seasonal amplitude at JAV was similar to, but less extreme than that at SIN and PEG. The floodplain at JAV apparently retains enough water from the wet season to allow greater evaporation through the early dry season than at the other two sites [Borma et al., 2009].

\section{Conclusions}

[21] The seven tower sites were easily divisible into two functional groups based on the seasonality of evaporation: tropical forest and savanna. Dry season length varied from 2 months in central Amazonia to 6 months in the south and east. The vegetation type at each site was closely associated with the dry season length along the gradient. Other factors were also almost certainly important in controlling vegetation distribution, such as mean annual temperature, annual precipitation, and geomorphology (especially at JAV, which is on a river floodplain).

[22] The two functional groups were different in their seasonality of water and energy fluxes. The more southern and eastern sites (SIN, JAV and PEG) were drier and showed an ET decrease during the dry season, reaching minimum values of $2.5 \mathrm{~mm} \mathrm{~d}^{-1}$ in the transitional forest and floodplain, and $1 \mathrm{~mm} \mathrm{~d}^{-1}$ in the cerrado sensu stricto. This decrease was likely due to soil moisture limitation. This pattern is typical of the Brazillian cerrado ecosystem, with its marked seasonality of leaf area index and green biomass resulting from leaf senescence and grass dormancy during the dry season. This created a situation where the seasonal patterns of ET at SIN, JAV and PEG were controlled mainly by the effect of soil moisture availability.

[23] The more northern and western sites (K34, K67, K83 and JRU) were wetter, with dry season length of less than 4 or 5 months. The annual precipitation at these sites was at least $1900 \mathrm{~mm}$, and the mean annual above-canopy temperature was above $25^{\circ} \mathrm{C}$. The mean monthly evaporation at the wetter sites increased during the dry season to as much as $4 \mathrm{~mm} \mathrm{~d}^{-1}$, and was relatively consistent during the wet season. ET, net radiation and vapor density deficit were positively correlated at these sites, and atmospheric conditions appear to exert the dominant control on ET. All of these sites were dominated by well-established forest, with trees that were presumably deeply rooted [cf. Bruno et al., 2006]. The combination of evergreen or semidecidous leaf phenology, extensive root systems, and the ability to extract soil moisture from deep in the soil column, apparently allow these sites to maintain high rates of ET throughout the dry season. This created a situation where the seasonal patterns of ET at K34, K67, K83 and JRU were controlled mainly by atmospheric evaporative demand.

[24] Acknowledgments. We thank the LBA scientific committee, the Brazilian Ministry of Science and Technology, the Brazillian funding agencies Fapesp, CNPq and Finep, the NASA/LBA-Eco coordination and staff, and all who contributed with constructive work during the last decade, including C. Nobre, J. Shuttleworth, D. Fitzjarrald, M. Keller, M. A. S. Dias, P. S. Dias, A. Araujo, O. Moraes, O. Acevedo, R. Sakai, L. Sá, J. Lloyd, J. Gash, L. Hutyra, M. Costa, F. Zanchi, A. Miranda, J. Grace, Y. Malhi, G. Fisch, R. Alvalá, R. Avissar, E. Collichio, F. Lobo, J. Tota,
R. Bruno, R. Tannus, L. Oliveira, R. Juarez, D. Kurzatkowski, and D. Rezende. The first author acknowledges Fapesp (02/09289-9) and CNPq (Instituto do Milênio, Ed. Universal-01, Ed. CT-Hidro 03).

\section{References}

Araújo, A. C., et al. (2002), Comparative measurements of carbon dioxide fluxes from two nearby towers in a central Amazonian rainforest: The Manaus LBA site, J. Geophys. Res., 107(D20), 8090, doi:10.1029/ 2001JD000676.

Betts, R., et al. (2004), The role of ecosystem-atmosphere interactions in simulated Amazonian precipitation decrease and forest dieback under global climate warming, Theor. Appl. Climatol., 78(1-3), 157-175.

Borma, L. S., et al. (2009), Atmospheric and hydrological controls of the evapotranspiration over a floodplain forest in the Bananal Island region, Amazonia, J. Geophys. Res., doi:10.1029/2007JG000641, in press.

Bruno, R. D., H. R. da Rocha, H. Freitas, M. Goulden, and S. Miller (2006), Soil moisture dynamics in an eastern Amazonian tropical forest, Hydrol. Process., 20, 2477-2489.

Costa, M., and J. Foley (1999), Trends in the hydrologic cycle of the Amazon basin, J. Geophys. Res., 104, 14,189-14,198.

da Rocha, H. R., H. C. Freitas, R. Rosolem, R. I. N. Juarez, R. N. Tannus, M. V. Ligo, O. M. R. Cabral, and M. A. F. Silva Dias (2002), Measurements of $\mathrm{CO}_{2}$ exchange over a woodland savanna (cerrado sensu stricto) in southeast Brasil, Biota Neotropica, 2(1). (Available at http:// www.scielo.br/scielo.php/script_sci_serial/lng_pt/pid_1676-0603/nrm_iso)

da Rocha, H. R., M. Goulden, S. Miller, M. Menton, L. Pinto, H. Freitas, and A. S. Figueira (2004), Seasonality of water and heat fluxes over a tropical forest in eastern Amazonia, Ecol. Appl., 14(4), 22-32.

Dirmeyer, P., and K. Brubaker (2007), Characterization of the global hydrologic cycle from a back-trajectory analysis of atmospheric water vapor, J. Hydrometeorol., 8(1), 20-37.

Friedlingstein, P., et al. (2006), Climate-carbon cycle feedback analys: Results from the CMIP-M4 model intercomparison, J. Clim., 19(14), 33373353 .

Gash, J. C. H., C. A. Nobre, J. M. Roberts, and R. Victória (1996), Amazonian Deforestation and Climate, pp. 1-14, John Wiley, Chichester, UK

Goulden, M., S. Miller, H. Rocha, M. Menton, and H. Freitas (2004), Physiological controls on tropical forest $\mathrm{CO}_{2}$ exchange, Ecol. Appl., 14(4), 42-55

Hutyra, L., J. Munger, S. Saleska, E. Gottlieb, B. Daube, A. Dunn, D. Amaral, P. Camargo, and S. Wofsy (2007), Seasonal controls on the exchange of carbon and water in an Amazonian rain forest, J. Geophys. Res., 112, G03008, doi:10.1029/2006JG000365.

Inmet (1994), Normais climatológicas de superfície 1931-1990, Inst. Nac. de Meteorol., Brasília, DF, Brasil.

Miller, S. D., M. L. Goulden, H. R. da Rocha, M. C. Menton, and H. C. Freitas (2004), Biometric and micrometeorological measurements of tropical forest carbon balance, Ecol. Appl., 14(4), suppl. S, 114-126.

Neiff, J. J. (2003), Planícies de inundação são ecótonos?, in Ecotonos nas Interfaces dos Ecossistemas Aquáticos, edited by R. Henry, cap. 2, pp. 32 47, RIMA Editora, São Carlos, Brazil.

Oliveira, R., et al. (2005), Deep root function in soil water dynamics in cerrado savannas of central Brazil, Funct. Ecol., 19, 574-581.

Saleska, S. R., et al. (2003), Carbon in Amazon forests: Unexpected seasonal fluxes and disturbance-induced losses, Science, 302, 1554-1557.

Saleska, S. R., K. Didan, A. R. Huete, and H. R. da Rocha (2007), Amazon forests green-up during 2005 drought, Science, 318, 612, doi:10.1126/ science. 1146663.

Shuttleworth, W. J. (1988), Evaporation from Amazonian rain forest, Proc. R. Soc. London, Ser. B, 233, 321-346.

von Randow, C., et al. (2004), Comparative measurements and seasonal variations in energy and carbon exchange over forest and pasture in southwest Amazonia, Theor. Appl. Climatol., doi:10.1007/s00704-0040041-z.

Vourlitis, G., et al. (2002), Seasonal variations in the evapotranspiration of a transitional tropical forest of Mato Grosso, Brasil, Water Resour. Res. 38(6), 1094, doi:10.1029/2000WR000122.

Wilson, K., et al. (2002), Energy balance closure at FLUXNET sites, Agric. For: Meteorol., 113(1-4), 223-243.

R. G. Aguiar and F. L. Cardoso, Universidade Federal de Rondonia, Porto Velho, RO 78900-000, Brazil.

P. Artaxo, L. S. Borma, H. R. da Rocha, and H. C. Freitas, Departamento de Ciências Atmosféricas, IAG, Universidade de São Paulo, Rua do Matão, 1226 Cidade Universitária, Sao Paulo, SP 05508-090, Brazil. (humberto@ model.iag.usp.br)

O. M. Cabral, Embrapa Meio Ambiente, Jaguariuna, SP 13.820-00, Brazil. 
M. L. Goulden, Department of Earth System Science, University of California, Irvine, CA 92697, USA

B. Kruijt, Wageningen University and Research, NL-6700 AA Wageningen, Netherlands.

J. F. Maia, A. O. Manzi, A. D. Nobre, and C. von Randow, Instituto Nacional de Pesquisas da Amazônia, Manaus, AM 69060-001, Brazil.

S. D. Miller, Atmospheric Sciences Research Center, State University of New York at Albany, Albany, NY 12203, USA.
J. S. Nogueira, Department of Physics, Universidade Federal de Mato Grosso, Cuiabá, MT 78005505, Brazil.

N. R.-Coupe and S. R. Saleska, Department of Ecology and Evolutionary Biology, University of Arizona, Tucson, AZ 85721, USA.

G. Vourlitis, Biological Sciences Department, California State University, San Marcos, CA 92096, USA.

S. C. Wofsy, Department of Earth and Planetary Sciences, Harvard University, Cambridge, MA 02138, USA. 